\title{
Target Costing Using Fuzzy Logic
}

\section{Tunay Aslan}

Istanbul Aydın University | tunay_aslan@hotmail.com

Gökhan Baral

Sakarya University | baral@sakarya.edu.tr

\section{Cüneyt Mucedidi}

Independent Researcher | cuneytmucedidi@gmail.com

Volume 7 No 1 (2017) ｜ＩSSN 2158-8708 (online) ｜ＤOI 10.5195/emaj.2017.123 | http://emaj.pitt.edu |

\begin{abstract}
Every business has to earn a profit in order to survive in a competitive environment and it has to plan the profitability it has targeted. Achieving the profitability that the business aimed is only possible by targeting its costs. It is only possible for businesses to achieve profitability that is targeted under uncertain conditions through the use of fuzzy logic method by approximately estimating the target costs. Therefore, the business will predict its target costs with the fuzzy logic method and reach the profitability that was aimed.
\end{abstract}

Keywords: Accounting, Target Costing, Fuzzy Logic, Profitability

\section{(c) $)$ EY}

New articles in this journal are licensed under a Creative Commons Attribution 3.0 United States License.

\section{UILIS D-Sente}

This journal is published by the University Library System of the University of Pittsburgh as part of its D-Scribe Digital Publishing Program, and is cosponsored by the University of Pittsburgh Press. 


\section{Target Costing Using Fuzzy Logic}

\author{
Tunay Aslan \\ Gökhan Baral \\ Cüneyt Mucedidi
}

\section{1- Introduction}

Since today's world includes various uncertainties, both individuals and businesses need to make decisions under conditions of uncertainty. It is only possible for businesses to survive under the increasing and almost deadly competitive environment by taking correct and reliable decisions. Markets in today's world have many uncertainties and therefore, businesses have to pass decisions under these uncertain conditions (Baral, 2016).

Businesses have to make consistent calculations and need logical decisions. If there are historical data from decision-makers and businesses believe these data will not change, then, it is possible for them to pass objective and almost realistic decisions. However, without historical data from the decisionmakers or if the businesses do not believe in the reliability of these historical data, then experts have to pass subjective decisions based on their personal judgments and intuitions. While it is not claimed that these approaches will reveal certain information, it may have an almost-realistic outcome.

It is only possible for businesses to succeed in a competitive environment and achieve the profitability they have targeted under a successful cost control if the prices in the market are deemed as fixed. While businesses do not have the power alone to change the price in the market yet, they need target costs to achieve the profitability they aim (Kızıl and Kızıl, 2007).

Every business has to earn a profit in order to survive in a competitive environment and it has to plan the profitability it has targeted. Achieving the profitability that the business aimed is only possible by targeting its costs. It is only possible for businesses to achieve profitability that is targeted under uncertain conditions through the use of fuzzy logic method by approximately estimating the target costs. Therefore, the business will predict its target costs with the fuzzy logic method and reach the profitability that was aimed.

This study consists of four sections and presents the theoretical structure of fuzzy logic in the second section, the target costing in the third and the model for using target costing with fuzzy logic has been developed in the fourth part. The results section lists the findings.

\section{2- Fuzzy Logic}

Artificial intelligence has been defined as the science of smart machines and creating smart computer programs by McCarthy for the first time in the history of the world. It is possible to come across different definitions on artificial intelligence in the literature. According to Hopgood, artificial intelligence is "the science of imitating cognitive capabilities of humans" (Hopgood, 2003). Another definition says artificial intelligence is the computer use area created by operational mechanisms to perform works that people carry out by using their intelligence (Partridge, 1998). It is possible to unite these definitions under four main titles (Russell and Norvig, 1995):

- $\quad$ Thinking humanly

- Acting humanly

- Rational thinking

- $\quad$ Rational acting

There are many other branches under artificial intelligence in the literature. These in general are: fuzzy logic, artificial neural networks, expert systems, machine intelligence, genetic algorithms, genetic programming, pattern recognition, speaking recognition, speaking synthesis, and learning by multiple-examples (Birgili et al, 2013).

As a sub-branch of artificial intelligence, fuzzy logic is a strong problem solving method for most of audit and information processes. It takes into consideration fuzzy information in situations that are not certain and includes uncertainties, and enables getting accurate results simply (Zadeh: 1865). Fuzzy logic is scientific expression of the existence of various degrees of grey developed by Zadeh against the black and white duality of Aristo. Definitions in fuzzy logic enable the use of uncertain assertions.

In other words, Aristo's classical set theory is a structure in mathematics that is defined by very strict rules. This structure consists of sets and elements that are either included or not in a set. Such certainty creates differentiation between elements and membership of an element to the set is assessed as either by a yes or no and is certain. This goes for all deterministic and probabilistic situations. Membership of classical sets is a dual function; in other words, receives the value of either a 0 or a 1. Verbally, this means that all colors are either black or white. A color has to be included in one or the other set.

However, this changes in fuzzy sets. Membership characteristic is not a dual function and does not only receive the value of a 0 or a 1 . Belonging to a set is 
shown with a membership function and can take all values between 0 and 1 . Verbally, colors will become distant to dual; they will not just be black and white but may take all tones of gray in between (Feng et al. 2010). This change arises due to uncertainties in natural languages and life not having a precision (Ross, 2009).

Fuzzy Inference Systems (FIS) are mainly used for transforming inputs to outputs. First, the numeric inputs are fuzzed, on other words are separated into classical sets. Depending on their values, rules are affected in rules database and rules that are suitable for the inputs are operated. A total area is created for each input with the rules operated according to Mamdani style. These areas form the areas of fuzzy output, which is the provision of the input areas that are fuzzed. Fuzzy outputs are turned into numeric values through inference algorithms and form the results of the output system. The same operation is performed for all inputs. In order to create properly working FIS, first all inputs and outputs need to be fuzzed. An example of fuzzy logic inference system is presented in the figure below (Rebizant and Feser, 2001):

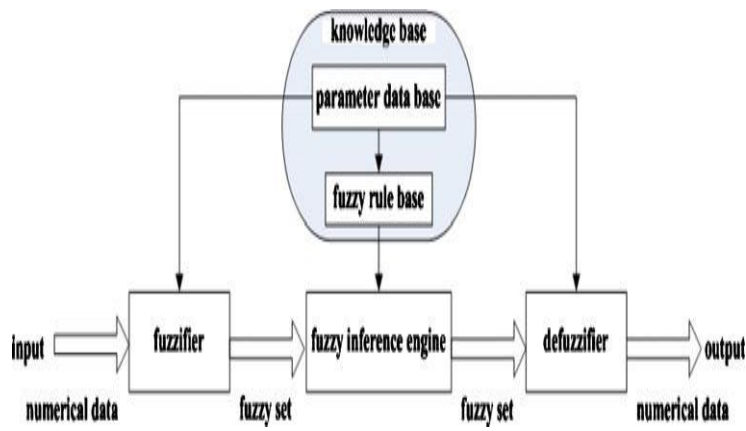

Figure 1. General Fuzzy Inference System

For a Mamdani-style fuzzy logic inference system, inputs are defined in fuzzy sets. The structures of these sets, which also introduce membership functions, vary. The widely used fuzzy methods are triangle, trapezoid, gauss and general bell membership functions. It is important to determine the most suitable membership functions depending on the distribution of the data or the model. As an example; for linear models, triangle or trapezoid is used. For non-linear models, Gaussian or Gbell is used (Lorestani et al. 2006).

\section{3- Target Costing}

Globalization and technological developments shorten life of products of businesses and the desires and requirements of customers constantly change. With these developments, classical cost methods don't meet the requirements of businesses. In other words, modern costing methods are needed. Modern cost methods provide a competitive advantage to businesses in the market by offering effective cost information. Success and existence of businesses in the market require modern cost methods and the reliable cost information is crucial for determining the costs of products. While there are many modern cost methods due to globalization and technological developments, we will only focus on the target costing method in order to support implementation (Pazarçeviren and Celayir, 2013).

The target costing method was used for the first time in 1965 by Toyota and its application area has been extended since then. The Japanese Toyota factory created this cost method to establish a relationship between its products and costs and to develop a strategy accordingly. Target costing method aims to use as a cost management system especially in markets where prices are deemed as data, in order to reach the aimed profit through controlling costs. Through this cost method, employees of the business will control the costs in order to reach the aimed profit (Gagne et al., 1995).

There are different definitions of Target Costing in the literature. According to Tani, target costing "defends planning of costs at the design stage of products and aims to reach a strategic profit through the targeted cost" (Tani, 1995). Another definition says target costing involves the reviewing of all ideas suggested for lowering costs at planning, research and development stages of a new product and lowering all costs through the life cycle of a product without sacrificing from quality and customer's requirements. This cost management is a technique that lowers costs of businesses before any activities, in other words, without starting production (Kaya, 2010). The purposes of target costing method differ from business to business. The main goals of target costing method can be summarized as follows:

- Ensuring integration of the whole business to the market

- Realizing the quality level required for the market

- Introducing new products at the right time to the market

- $\quad$ Meeting customer requirements by discovering qualities of the product

The target costing method is a technique based mainly on two factors. These are sales prices and targeted profitability. Businesses can only reach their targeted profitability by accepting price as an input through the target costing method. This is a method in which the business deducts its targeted profitability from the sales price of a product. Unlike the traditional cost approach, in the target costing method, cost is not a function of additional costs, but a function of the sales price and the aimed profit (Pazarçeviren and Celayir, 2013). In other words, target cost can be be shown mathematically as follows: 
Target Cost $=$ Sales Price - Target Profit

Therefore, when calculating the target costs, it is necessary to determine the target sales price and profit margin required for the market share. The target sales price is the sale price determined according to the value the manufacturers place on the product. When determining the target sales price, the prices of rival products and the solvency of the consumers are considered. The target profit margin is the profit margin determined according to the long-term profit planning of the business. The difference between the sales price and the profit margin gives the target cost (Aksoylu and Dursun, 2011).

The figure below explains the target costing process. Accordingly, the target costing starts from the product design stage and continue through all the activities taking place within the whole life cycle of the product and its success is only possible with wide participation. All departments and suppliers in the business should serve this purpose.

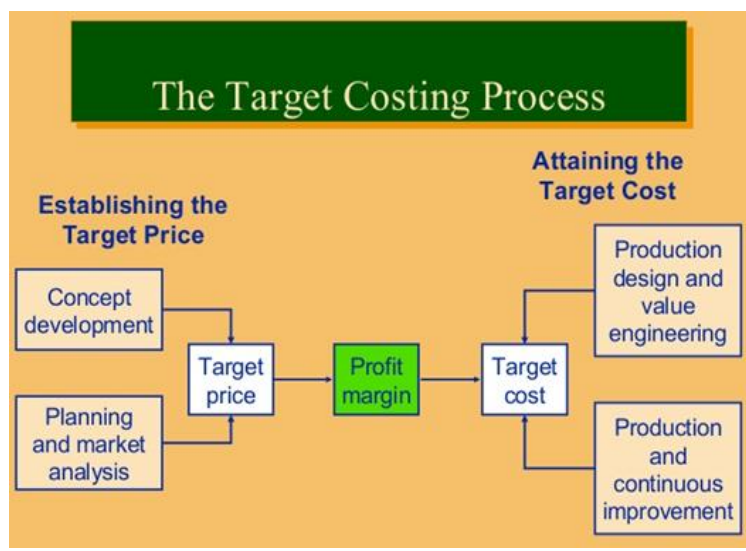

Figure 2. Target Costing Process

Target costing is based on six basic principles (Gopalakrishnan et al., 2007; Swenson et al., 2006). These can be summarized as follows:

Price-based Costing: The targeted cost is derived by subtracting the target profit from the competitive market price of the business.

Target cost: Sales Price- Target Profit

Customer Focus: While the target costing process aims at achieving the desired profit, it needs to take into consideration customer requirements and should not compromise quality while lowering costs to the aimed level.

Valuing Design Activity: Target costing is run for the design of products and processes. Business should spend more time on the design process in order to avoid expensive and time-consuming changes that may be required in the future.
Comprehensive Participation: Target costing method consists of processes such as design and production engineering, production, marketing, purchasing, cost accounting and auxiliary services and the success depends on coordination between departments.

Life Cycle Approach: The main goal of this method is to reduce the cost of the product from both the point of view of customers and the life cycle. In the life cycle approach, the costs cover all costs arising from the design phase to the sales phase.

Implementation of the Value Chain: This means that all groups related to the business are involved in the target costing process.

\section{4- Fuzzy Target Costing}

The implementation part of the study will include modeling by using fuzzy logic and target costing method. The target costing of the laboratory department of a health institution that has commenced its activities in 20XX in order to reach its targeted profitability rates will be carried out by MATLAB package program, included in the fuzzy logic method. The approximate loss and profit of the business will be calculated through this method and the target cost will also be determined.

\subsection{Laboratory Department Memberships}

Our entry-level memberships in the laboratory department are determined as Fixed Cost (FC), Variable Cost (VC) and Sales Revenue (SR) and our output variable is defined as Profit.

Table 1: Laboratory Department Memberships

\begin{tabular}{|c|c|c|c|}
\hline $\begin{array}{l}\text { INPUT } \\
\text { VARIABLES }\end{array}$ & RANGE & $\begin{array}{l}\text { LINGUISTIC } \\
\text { VARIABLES }\end{array}$ & PARAMETERS \\
\hline \multirow{3}{*}{$\begin{array}{l}\text { Sales Revenue } \\
\text {-SR }\end{array}$} & \multirow{3}{*}{$\begin{array}{l}0- \\
50.167 .00 \\
0 \mathrm{TL}\end{array}$} & Low & $0-20.000 .000$ \\
\hline & & Moderate & $\begin{array}{l}5.000 .000- \\
45.000 .000\end{array}$ \\
\hline & & High & $\begin{array}{l}30.000 .000- \\
50.167 .000\end{array}$ \\
\hline \multirow{3}{*}{$\begin{array}{l}\text { Variable Cost - } \\
\text { VC }\end{array}$} & \multirow{3}{*}{$\begin{array}{l}0- \\
30.469 .10 \\
5 \mathrm{TL}\end{array}$} & Low & $0-11.000 .000$ \\
\hline & & Moderate & $\begin{array}{l}4.000 .000- \\
27.000 .000\end{array}$ \\
\hline & & High & $\begin{array}{l}19.000 .000- \\
30.469 .105\end{array}$ \\
\hline \multirow{3}{*}{$\begin{array}{l}\text { Fixed Cost } \\
\text { (FC) }\end{array}$} & \multirow{3}{*}{$\begin{array}{l}0- \\
2.800 .420 \\
\text { TL }\end{array}$} & Low & $0-1.100 .000$ \\
\hline & & Moderate & $\begin{array}{l}400.000- \\
2.500 .000\end{array}$ \\
\hline & & High & $\begin{array}{l}1.700 .000- \\
2.8000 .420\end{array}$ \\
\hline $\begin{array}{l}\text { OUTPUT } \\
\text { VARIABLES }\end{array}$ & RANGE & $\begin{array}{l}\text { LINGUISTİC } \\
\text { VARİABLES }\end{array}$ & PARAMETERS \\
\hline
\end{tabular}




\begin{tabular}{|l|l|l|l|} 
& & Low & $0-7.000 .000$ \\
\cline { 3 - 4 } PROFIT & $0-$ & & $1.900 .000-$ \\
& 16.897 .47 & Moderate & 15.000 .000 \\
\cline { 3 - 4 } & $5 \mathrm{TL}$ & & $11.000 .000-$ \\
& & High & 16.897 .475 \\
\hline
\end{tabular}

The linguistic variables and the range of these variables are determined as input and output variables required for the profitability analysis of the laboratory department are shown in the table below by forming a triangle membership function.

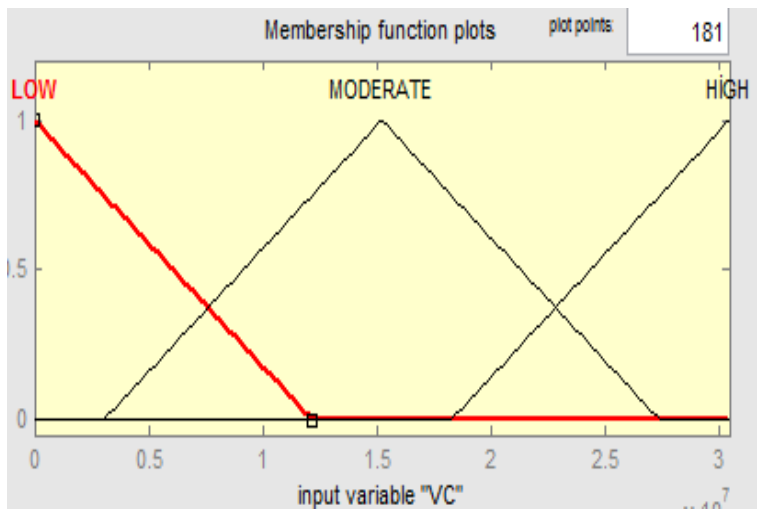

Figure 3. Variable Cost Membership Range

The rectangle membership function showing the variables of variable cost membership is shown above. If the variable cost is approximately below 4,000,000 TL, it belongs to the lower set with full membership degree. If the variable cost is below 27,000,000 TL, again with full membership degree, it belongs to the high set.

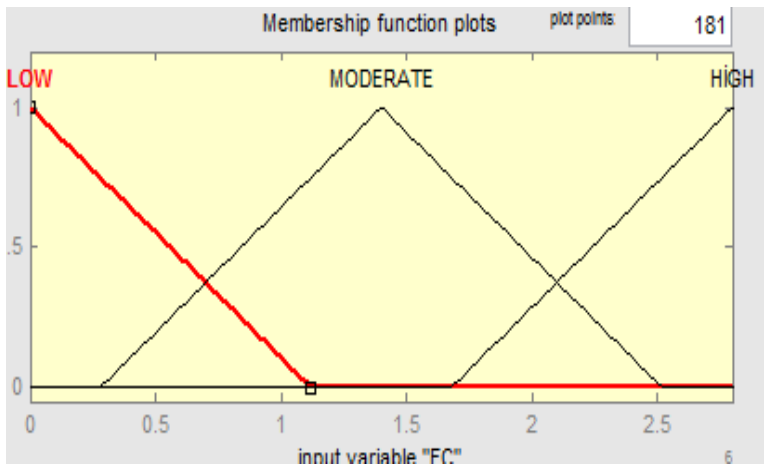

Figure 4. Fixed Cost Membership Range

Angle membership has been used for the fixed cost linguistic variable and the change ranges are shown and the membership values are also indicated in the above figure.

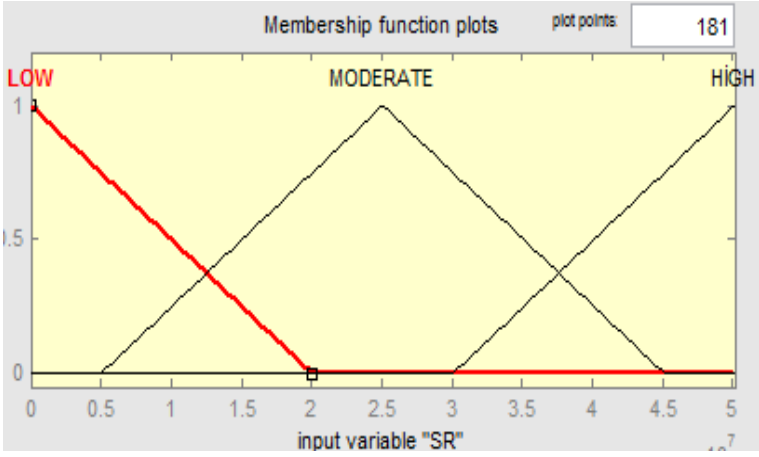

Figure 5. Sales Income Membership Range

Sales income triangle membership function ranges are depicted above. Linguistic variables and range parameters are created by benefiting from the experiences of expert managers.

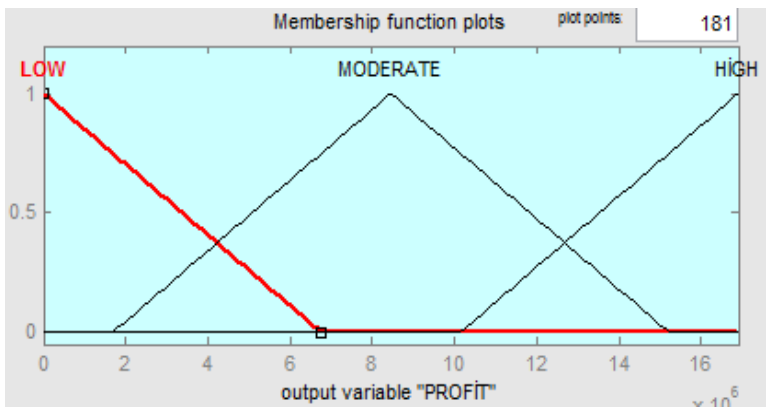

Figure 6. Profit Membership Ranges

The membership function and change ranges used for profit output variable are indicated above.

\subsection{Fuzzy Rules}

In the fuzzy logic system, relationship between input and output are established based on rules. This rule base is created by if-then-else structures. As fuzzy operators "and, or not" processors are used. A total of 27 rules are given to classify the costs of the laboratory department below. Rules are created with the support of experts. 


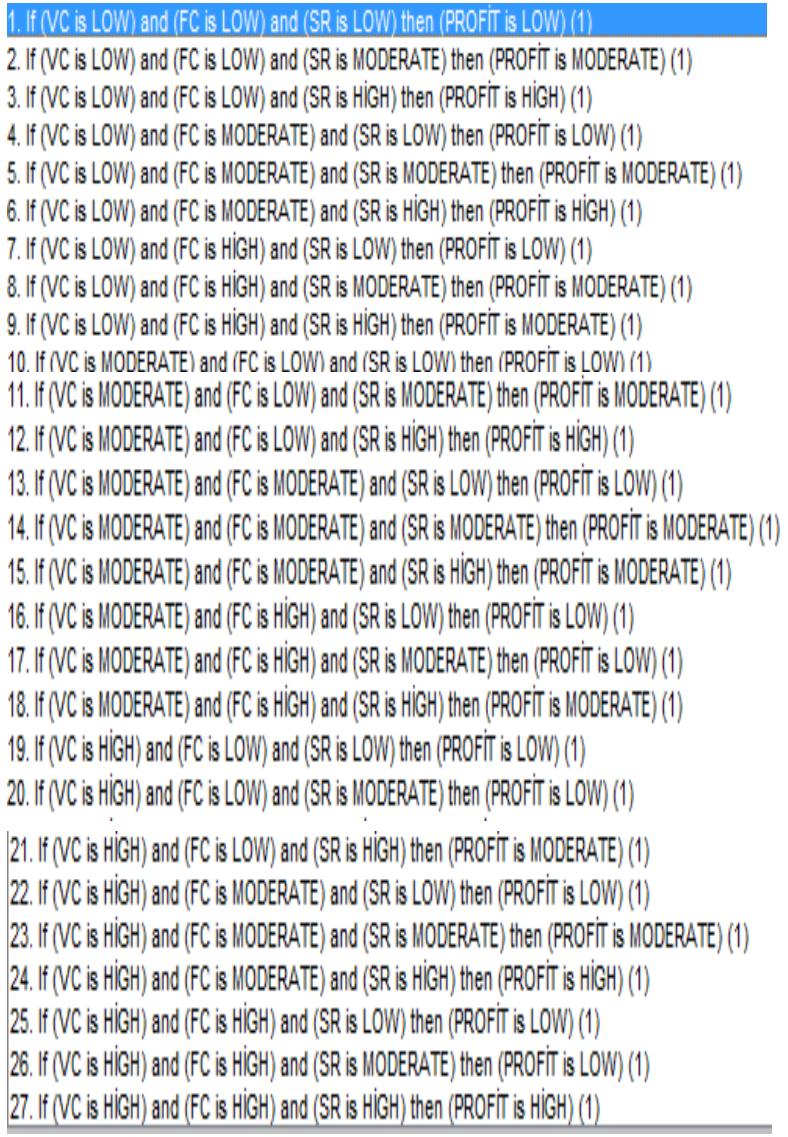

\subsection{Resolution of Fuzziness}

Inferences are created from the fuzzy information obtained from fuzzy system and the rulebase. The midpoint of maximums has been selected as a clarification method for determining the profitability results. Thus, the output variable (profit) is shown below and the results acquired when compared to the actual profit of the business reveal that they are close to the real situation.

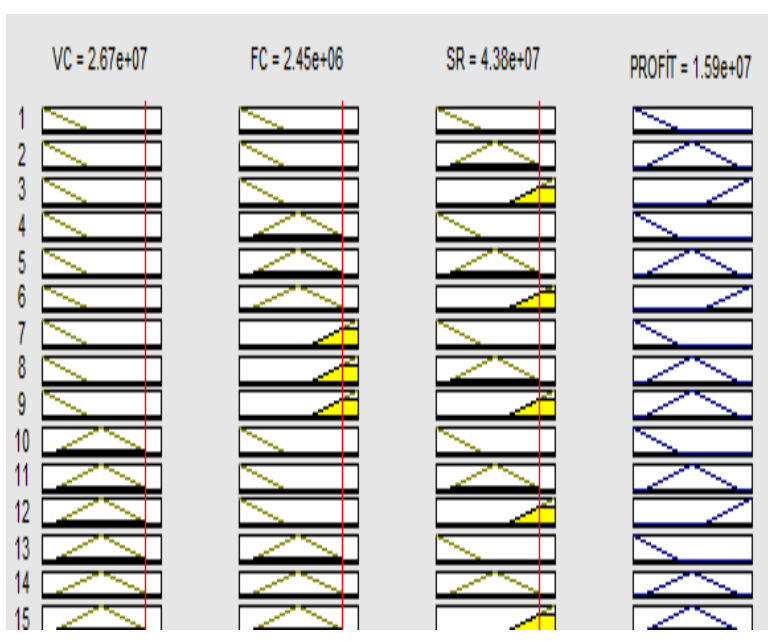

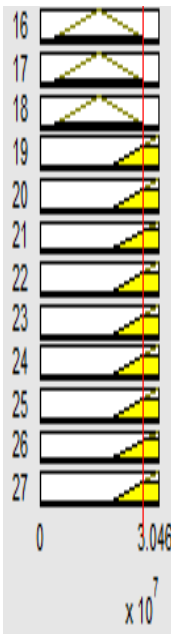
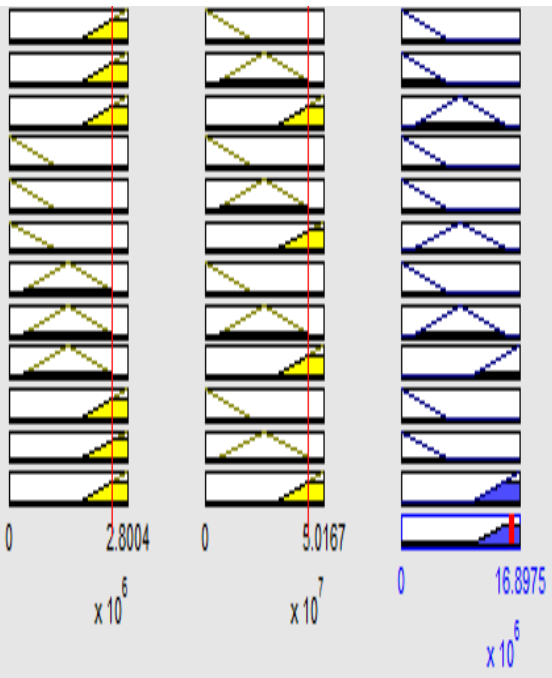
Figure 7. Resolution of Fuzziness - Output Variable
(Profit)

\section{5- Results}

Fuzzy logic is an expert system that does not include certainty. It can decide or guess using verbal expressions and numerical data together under uncertain situations. Numerical data and verbal (linguistic) expressions coexist in decision making or predictive analysis. Thus, difficult and complicated situations can be resolved with the help of computers. Businesses have to make consistent calculations and need logical decisions. If there are historical data from decisionmakers and businesses believe these data will not change, then, it is possible for them to pass objective and almost realistic decisions.

However, without historical data from the decision-makers or if the businesses do not believe in the reliability of these historical data, then experts have to pass subjective decisions based on their personal judgments and intuitions. While it is not claimed that these approaches will reveal certain information, it may have an almost-realistic outcome. It is only possible for businesses to succeed in a competitive environment and achieve the profitability they have targeted under a successful cost control if the prices in the market are deemed as fixed. Every business has to earn profits in order to survive in a competitive environment and it has to plan the profitability it has targeted.

Achieving target profitability is only possible by targeting the costs without sacrificing quality. It is only possible for businesses to achieve profitability that is targeted under uncertain conditions through the use of fuzzy logic method by approximately estimating the target costs. Therefore, the business will predict its target costs with the fuzzy logic method and reach the profitability that was aimed. 
The implementation model consists of 3 inputs (fixed cost, variable cost, sales revenue) and 1 output (profit). In the model, Mamdami fuzzy inference has been used and as a clarification method, the midpoint of maximums has been utilized as it gives more realistic results. The resulting actual value of $15,947,000$ TL with fuzzy logic was close to the actual value $(16,897,475)$ with an acceptable error rate of $5 \%$.

By using fuzzy logic method, businesses can predict and make decisions in uncertain situations. This study shows the success of fuzzy logic method in estimation. For further studies and future research, a similar research can be carried out by using artificial neural networks to determine which method is more successful in estimation.

\section{REFERENCES}

Aksoylu,S,.and Dursun,Y,. (2011), Pazarda Rekabetçi Üstünlük Aracı Olarak Hedef Maliyetleme, Sosyal Bilimler Dergisi Sayı:11,358-370, p.362.

Ansari, Shadid, Bell, Janice, Swenson. Dan (2006), A Template for Implementing Target Costing, Cost Management, Cilt. 20, Sayı. 5, pp. 20-27.

Baral,G,.(2016). Cost-Value-Profit Analysis and Target Costing with Fuzzy Logic Theory, Mediterranean Journal of Social Sciences, V:7(2), pp.21-29.

Birgili.,E.,Sekmen.,F.,Esen.,S.,(2013). Bulanık Mantık Yaklaşımı ile Finansal Yöntem Uygulamaları: Bir Literatür Taraması, Uluslararası Yönetim ve İşletme Dergisi, 9. pp.121-136.

Feng, F., Li, C., Davvaz, B., and Ali, M. I. (2010). Soft sets combined with fuzzy sets and rough sets: a tentative approach. Soft Computing, 14(9), pp. 899-911.

Gagne,M,., Discenza,R,.(1995),Journal of Business and Industrial Marketing,Vol:10,pp 16-22.

Gopalakrishnan, Mohan, Samuels Janet, Swenson Dan (2007), Target Costing at a Consumer Products Company, Strategic Finance, Sayı. Aralık, pp. 37-41.

Hopgood, A. A. (2003). Artificial intelligence: hype or reality? Computer, 36(5), pp.24-28.

Kaya,G,.(2010),Hedef Maliyetleme,Firat Üniversitesi Sosyal Bilimler Dergisi, 20(1), pp.313-332.

Kızıl, Ahmet, Kız1l, Cevdet (2007), Accounting: Financial, Cost, Managerial, Bahar Yayınevi (Bahar Publishing), p.238.
Lorestani, A. N., Omid, M., Bagheri-Shooraki, S., Borghei, A. M., and Tabatabaeefar, A. (2006). Design and evaluation of a fuzzy logic based decision support system for grading of Golden Delicious apples. Int J Agric Biol, 8(4), pp. 440-444.

Partridge, D. (1998). Artificial Intelligence in Software Engineering. John Wiley \& Sons, Inc.

Pazarçeviren,S,.Celayir,D,.(2013), European Scientific Journal ,V:4, pp 1-21.

Rebizant, W., and Feser, K. (2001). Fuzzy logic application to out-of-step protection of generators. In Power Engineering Society Summer Meeting, 2001 v. 2, pp. 927-932.

Ross, T. J. (2009). Fuzzy logic with engineering applications. John Wiley \& Sons.

Russell, S., Norvig, P. (1995). A modern approach. Artificial Intelligence. Prentice-Hall, Egnlewood Cliffs.

Takeyuki,Tani,.(1995), Interactive Control in Target Cost Management Accounting Research,Volume:6, pp.399-414.

Zadeh, L. A. (1965). Fuzzy sets, information control, 1( 8), pp.338-353. 